DiReCteur de LA PUblication / PUBLICATION DIRECTOR: Bruno DAVID

Président du Muséum national d'Histoire naturelle

RÉDACTEUR EN CHEF / EDITOR-IN-CHIEF : Bart BUYCK

ASSISTANTE DE RÉDACTION / ASSISTANT EDITOR: Audrina NEVEU (myco@cryptogamie.com)

Mise en PAge / PAge LAyout: Audrina NEVEU

RÉdACTEURS ASSOCIÉS / ASSOCIATE EDITORS:

Slavomír ADAM ÍK

Institute of Botany, Plant Science and Biodiversity Centre, Slovak Academy of Sciences, Dúbravská cesta 9, SK-84523, Bratislava (Slovakia)

André APTROOT

ABL Herbarium, G.v.d. Veenstraat 107, NL-3762 XK Soest (The Netherlands)

Cony DECOCK

Mycothèque de l'Université catholique de Louvain, Earth and Life Institute, Microbiology, Université catholique de Louvain,

Croix du Sud 3, B-1348 Louvain-la-Neuve (Belgium)

André FRAITURE

Botanic Garden Meise, Domein van Bouchout, B-1860 Meise (Belgium)

Kevin D. HYDE

School of Science, Mae Fah Luang University, 333 M. 1 T.Tasud Muang District, Chiang Rai 57100 (Thailand)

Valérie HOFSTETTER

Station de recherche Agroscope Changins-Wädenswil, Dépt. Protection des plantes, Mycologie, CH-1260 Nyon 1 (Switzerland)

Sinang HONGSANAN

College of Life Science and Oceanography, Shenzhen University, 1068, Nanhai Avenue, Nanshan, ShenZhen 518055 (China)

Egon HORAK

Schlossfeld 17, A-6020 Innsbruck (Austria)

Jing LUO

Department of Plant Biology \& Pathology, Rutgers University New Brunswick, NJ 08901 (United States)

Ruvishika S. JAYAWARDENA

Center of Excellence in Fungal Research, Mae Fah Luang University, 333 M. 1 T.Tasud Muang District, Chiang Rai 57100 (Thailand)

Chen JIE

Instituto de Ecología, Xalapa 91070, Veracruz (México)

Sajeewa S.N. MAHARCHCHIKUMBURA

Department of Crop Sciences, College of Agricultural and Marine Sciences, Sultan Qaboos University (Oman)

Pierre-Arthur MOREAU

UE 7144. Faculté des Sciences pharmaceutiques et biologiques. Université Lille Nord de France. F-59006 Lille (France)

Tian QING

Center of Excellence in Fungal Research, Mae Fah Luang University 333 M. 1 T.Tasud Muang District, Chiang Rai 57100 (Thailand)

Sylvie RAPIOR

Laboratoire de Botanique, Phytochimie et Mycologie / UMR -CNRS 5175 CEFE, Faculté de Pharmacie, 15, avenue Charles-Flahault,

Université Montpellier I, BP 14491, 34093 Montpellier Cedex 5 (France)

Franck RICHARD

Université de Montpellier II, CEFE/CNRS Campus du CNRS, 1919, route de Mende, 34293 Montpellier Cedex 5 (France)

Naritsada THONGKLANG

Center of Excellence in Fungal Research, Mae Fah Luang University, 333 M. 1 T.Tasud Muang District, Chiang Rai 57100 (Thailand)

Xiang-Hua WANG

CAS Key Laboratory for Plant Diversity and Biogeography of East Asia, Kunming Institute of Botany,

Chinese Academy of Sciences, Lanhei Road 132, Kunming 650201, P. R. (China)

COUVERTURE / COVER:

Extraits d'éléments de la Figure 3 / Extracts of the Figure 3

Cryptogamie, Mycologie est indexé dans / Cryptogamie, Mycologie is indexed in:

- Biological Abstracts

- Current Contents

- Science Citation Index

- Publications bibliographiques du CNRS (Pascal).

Cryptogamie, Mycologie est distribué en version électronique par / Cryptogamie, Mycologie is distributed electronically by:

- BioOne ${ }^{\circledR}$ (http://www.bioone.org/loi/crym)

Cryptogamie, Mycologie est une revue en flux continu publiée par les Publications scientifiques du Muséum, Paris Cryptogamie, Mycologie is a fast track journal published by the Museum Science Press, Paris

Les Publications scientifiques du Muséum publient aussi / The Museum Science Press also publishes: Adansonia, Geodiversitas, Zoosystema, Anthropozoologica, European Journal of Taxonomy, Naturae, Cryptogamie sous-sections Algologie, Bryologie, Comptes Rendus Palevol.

Diffusion - Publications scientifiques Muséum national d'Histoire naturelle

CP 41 - 57 rue Cuvier F-75231 Paris cedex 05 (France)

Tél.: 33 (0)1 40794805 / Fax: 33 (0)1 40793840

diff.pub@mnhn.fr / http://sciencepress.mnhn.fr

C) Publications scientifiques du Muséum national d'Histoire naturelle, Paris, 2020

ISSN (imprimé / print): 0181-1584/ ISSN (électronique / electronic): 1776-100 


\title{
Three novel species of Russula Pers. subg. Compactae (Fr.) Bon from Dinghushan Biosphere Reserve in southern China
}

\author{
Songyan ZHOU* \\ State Key Lab of Biocontrol, School of Life Science, \\ Sun Yat-sen University, Guangzhou 510275 (China)
}

* Equal contributions

Yu SONG*

Shaanxi Key Laboratory of Bio-Resources, School of Biological Science \& Engineering, Shaanxi University of Technology, Hanzhong 723000 (China)

* Equal contributions

Kaixing CHEN

Jingwei 니

State Key Lab of Biocontrol, School of Life Science, Sun Yat-sen University, Guangzhou 510275 (China)

Bart BUYCK

Institut de Systématique, Écologie, Biodiversité (ISYEB), Muséum national d'histoire naturelle, CNRS, Sorbonne Université,

EPHE, 57 rue Cuvier, CP 39, F-75005 Paris (France)

buyck@mnhn.fr

Lihong QIU

State Key Lab of Biocontrol, School of Life Science, Sun Yat-sen University, Guangzhou 510275 (China) qiulh@mail.sysu.edu.cn (corresponding author)

Submitted on 23 June 2020 | Accepted on 2 September 2020 | Published on 24 November 2020

KEY WORDS

Multilocus,

phylogeny,

southern China,

new species.
Zhou S., Song Y., Chen K., Li J., Buyck B. \& Qiu L. 2020. - Three novel species of Russula Pers. subg. Compactae (Fr.) Bon from Dinghushan Biosphere Reserve in southern China. Cryptogamie, Mycologie 41 (14): 219-234. https:// doi.org/10.5252/cryptogamie-mycologie2020v41a14. http://cryptogamie.com/mycologie/41/14

\section{ABSTRACT}

Three novel species of Russula Pers. subg. Compactae (Fr.) Bon from southern China are described with morphological evidence and phylogenetic analyses based on ITS and the concatenated partial LSU, mtSSU, rpb1, rpb2 and tef1 gene sequences. All three species possess sparse and broad lamellae. Russula latolamellata Y.Song \& L.H.Qiu, sp. nov., is characterized by its cracking, black-tan pileus, scarlet-turning context on bruising and absence of pileocystidia and caulocystidia. Russula nigrocarpa S.Y.Zhou, Y.Song \& L.H.Qiu, sp. nov., can be distinguished by its off-white lamellae, small basidiospores, hymenial cystidia and pileocystidia of various forms, often with forked apices and by its gelatinous pileipellis. Russula ochrobrunnea S.Y.Zhou, Y.Song \& L.H.Qiu, sp. nov., is characterized by its cracking, grayish brown pileus with striate margin, light-brown lamellae whose edges turn dark-brown when mature, small basidiospores and slightly flexuous ormoniliform hymenial cystidia. Their detailed morphological features and phylogenetic positions are discussed and compared among closely related species. 


\begin{abstract}
RÉSUMÉ
Trois nouvelles espèces de Russula Pers. subg. Compactae (Fr.) Bon provenant du sud de la Chine. Trois nouvelles espèces de Russula Pers. subg. Compactae (Fr.) Bon provenant du sud de la Chine, toutes possédant des lamelles distantes et larges, sont illustrées et décrites sur la base d'arguments morphologiques et d'analyses phylogénétiques fondées sur l'ITS et les séquences partielles concaténées des gènes LSU, mtSSU, rpb1, rpb2 et tef1. Russula latolamellata Y.Song \& L.H.Qiu, sp. nov., se caractérise par la surface brun noirâtre, finement aréolée de son chapeau, sa chaire devenant rouge écarlate à la coupe, la présence fréquente de basides monospores et l'absence de pileo- et caulocystides. Russula nigrocarpa S.Y.Zhou, Y.Song \& L.H.Qiu, sp. nov., se caractérise par ses lamelles blanc cassé à arête brun foncé à noire à maturité, les cystides hyméniales et pileocystides de forme variable et son pileipellis gélifié. Russula ochrobrunnea S.Y.Zhou, Y.Song \& L.H.Qiu, sp. nov., se caractérise par son chapeau gris-brun à marge striée, ses lamelles brun clair à arête brun foncé à maturité, la présence de basides monospores et ses cystides hyméniales légèrement sinueuses ou moniliformes. Leurs caractéristiques morphologiques détaillées et leurs positions phylogénétiques sont discutées et comparées avec les espèces étroitement apparentées.
\end{abstract}

MOTS CLÉS

Multi-genes,

phylogénie, sud de la Chine, espèces nouvelles.
Recently, in a survey for Russula carried out by the authors in Dinghushan Biosphere Reserve (DHSBR, 112³0'39"$112^{\circ} 33^{\prime} 41^{\prime \prime} \mathrm{E}, 23^{\circ} 09^{\prime} 21^{\prime \prime}-23^{\circ} 11^{\prime} 30^{\prime \prime} \mathrm{N}$ ), a well-known reserve located in Guangdong Province, P. R. of China, 13 new species and one epitype (Das et al. 2017; Zhang et al. 2017; Song et al. 2018a, b; Li et al. 2018; Yuan et al. 2019), all belonging to $R$. subg. Heterophyllidiae Romagn., have been recovered and published. In this study, we report three novel species belonging to $R$. subg. Compactae collected from DHSBR during the survey. It is the first time that new species of this subgenus are reported from China.

\section{MATERIAL AND METHODS}

\section{SAMPLING AND MORPHOLOGY}

Specimens were collected from Dinghushan Biosphere Reserve

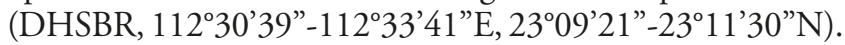
Specimens were dehydrated at $50-60^{\circ} \mathrm{C}$ and deposited in the Herbarium of Microbiology Institute of Guangdong (GDGM). Fresh basidiomata were photographed using Canon IXUS 220 hs digital camera or Canon EOS M50 under daylight in the field, and macroscopic characteristics were recorded. Macromorphological descriptions are based on the field notes and photographs taken from fresh basidiomata. Microscopic characters were observed under a Nikon Eclipse Ni-U microscope from hand-sectioned dried materials. Scanning electron images of basidiospores were captured with a Field Emission Scanning Electronic Microscope (JSM-6330F). Basidiospores were examined in Melzer's reagent and measured in side view, excluding ornamentations. Other micromorphological structures (basidia, hymenial cystidia, dermatocystidia, elements of pileipellis and stipitipellis) were observed from hand-sectioned dried tissues rehydrated in $5 \%$ or $10 \% \mathrm{KOH}$ solution and then mounted with $1 \%$ aqueous Congo red reagent. All tissues were examined in cresyl blue (Buyck 1989) to verify presence of ortho- or metachromatic reactions. Sulphovanillin 
TABLE 1. - Sequences used in phylogenetic analysis based on ITS. Specimens in bold correspond to new species.

\begin{tabular}{|c|c|c|c|}
\hline Taxon & Voucher specimen & Location & $\begin{array}{l}\text { ITS accession } \\
\text { number }\end{array}$ \\
\hline R. acrifolia Romagn. & UE12.09.2003-3 (UPS) & Sweden & DQ421998 \\
\hline R. adusta (Pers.) Fr. & Buyck 6020 (PC) & Europe & AY061652 \\
\hline$R$. aff. earlei Peck & Ex1186/BB 07.108 (PC) & Europe & KY800363 \\
\hline R. albonigra (Krombh.) Fr. & AT2002064 (UPS) & Sweden & DQ422029 \\
\hline R. anthracina Romagn. & LAH-EM2-2013 & Pakistan & KR011881 \\
\hline$R$. archaea R.Heim & BB2004-255 (PC) & United States & EU598165 \\
\hline R. archaeosuberis Sarnari & 1118/BB 12.085 & Italy & KY800355 \\
\hline R. butyroindica K.Das \& Buyck & CAL1511 (holotype) & India & KY674859 \\
\hline R. camarophylla Romagn. & PAM01081108 (PC) & France & DQ421982 \\
\hline R. camarophylla Romagn. & Sarnari 8/8/94 (PC) & Europe & AY061662 \\
\hline R. cantharellicola Romagn. & RG1 & United States & KF306037 \\
\hline R. cortinarioides Buyck, Adam ík, D.P.Lewis \& V.Hofst. & 567/BВ 07.103 & United States & KP033480 \\
\hline$R$. cf. eccentrica Peck & 431/BB 07.132 & United States & KP033478 \\
\hline R. densifolia Secr. ex Gillet & ue116 (TUB) & Germany & AF418606 \\
\hline R. dissimulans Shaffer & BPL285 (TENN) & United States & KT933979 \\
\hline R. earlei Peck & WRW00-412 (PC) & United States & DQ422025 \\
\hline R. earlei Peck & BPL245 (TENN) & United States & KT933961 \\
\hline R. eccentrica Peck & BB2004-248 (PC) & United States & EU598197 \\
\hline R. fortunae Corrales & TUC (Corrales 180) (holotype) & Panama & KM594806 \\
\hline R. fuliginosa Sarnari & IB 1992/0454 (holotype) & Italy & HG798529 \\
\hline R. glutinosa Fatto & Roody WRWV 04.1154 (holotype) & United States & MN315541 \\
\hline R. glutinosoides Buyck \& X.H.Wang & HKAS106678 (holotype) & China & MN434187 \\
\hline R. gossypina Buyck & 2/BB 06.002 & Madagascar & KY800350 \\
\hline R. khanchanjungae Van de Putte, K.Das \& Buyck & AV-KD-KVP09-106 (GENT) & India & KR364129 \\
\hline R. lateriticola (R.Heim) Singer & 7/BB 06.031 & Madagascar & KP033476 \\
\hline R. latolamellata Y.Song \& L.H.Qiu, sp. nov. & GDGM 79561 (holotype) & China & MN275543 \\
\hline R. latolamellata Y.Song \& L.H.Qiu, sp. nov. & GDGM 79562 & China & MN275544 \\
\hline R. latolamellata Y.Song \& L.H.Qiu, sp. nov. & GDGM 79563 & China & MN275545 \\
\hline R. nigricans Fr. & UE20.09.2004-07 (UPS) & Sweden & DQ422010 \\
\hline R. nigrocarpa S.Y.Zhou, Y.Song \& L.H.Qiu, sp. nov. & GDGM 79720 (holotype) & China & MN688794 \\
\hline R. nigrocarpa S.Y.Zhou, Y.Song \& L.H.Qiu, sp. nov. & GDGM 79721 & China & MN688795 \\
\hline R. ochrobrunnea S.Y.Zhou, Y.Song \& L.H.Qiu, sp. nov. & GDGM 79718 (holotype) & China & MN688792 \\
\hline R. ochrobrunnea S.Y.Zhou, Y.Song \& L.H.Qiu, sp. nov. & GDGM 79719 & China & MN688793 \\
\hline R. polyphylla Peck & 568/BB 07.023 & United States & KP033481 \\
\hline R. polyphylla Peck & 1194/BB 07.134 & United States & KP033486 \\
\hline R. pseudoaurantiophylla Buyck \& V.Hofst. & BB 09.223 (PC) (holotype) & New Caledonia & KY800354 \\
\hline R. subnigricans Hongo & OSA-MY-4267 & Japan & AB291750 \\
\hline
\end{tabular}

(SV) was used to test color reactions of cystidia (Sarnari 1998). Descriptive terminology followed Vellinga (1988). Color designation refers to HTML Color Codes (https:// htmlcolorcodes.com). The abbreviation $[\mathrm{x} / \mathrm{y} / \mathrm{z}]$ indicates that measurements were made on $\mathrm{x}$ basidiospores in $\mathrm{y}$ basidiomata from $\mathrm{z}$ collections. Basidiospore size and length/width ratio (Q) are given in the form of (a-) b-m-c (-d). The range b-c contains $95 \%$ of the measured values, a and $d$ refer to the extremes of all measurements, and m means average value.

\section{DNA EXTRACTION, PCR, SEQUENCING AND PHYLOGENETIC} ANALYSES

Genomic DNA was extracted from fresh fruiting bodies using a modified CTAB procedure of Doyle \& Doyle (1987). ITS was amplified using primer pair ITS 1 and ITS4 (White et al. 1990). The amplification protocol consists of a $5 \mathrm{~min}$ pre-degeneration at $94^{\circ} \mathrm{C}$, followed by 32 cycles of $30 \mathrm{~s}$ at $94^{\circ} \mathrm{C}, 30 \mathrm{~s}$ at $52^{\circ} \mathrm{C}$ and $1 \mathrm{~min}$ at $72^{\circ} \mathrm{C}$, and a final $12 \mathrm{~min}$ extension at $72^{\circ} \mathrm{C}$. LSU, mtSSU, rpb1, rpb2 and tef1 were amplified using the primers and protocols described in Buyck et al. (2018). The products obtained were purified using E.Z.N.A Gel Extraction Kit (OMEGA) and sequenced on an ABI3730xl DNA Analyzer (IGE, Guangzhou, China).
The newly generated sequences were deposited in GenBank (www.ncbi.nlm.nih.gov).

Blast query in GenBank with newly generated ITS sequences showed that three proposed novel species were assigned to Russula subg. Compactae. Phylogenetic analyses based on both ITS and combined sequences of LSU-mtSSU-tef1-rpb2-rpb1 were performed with Maximum Likelihood method. The datasets were automatically aligned by MAFFT v 7.427 (Katoh \& Standley 2013), then manually adjusted and trimmed with BioEdit v7.0.9 (Hall 1999). Ambiguous sites at the beginning, end and middle parts of the datasets were removed. The final ITS and 5-locus alignments comprised $759 \mathrm{bp}$ and $4163 \mathrm{bp}$ (LSU 904 bp, mtSSU 551 bp, tef1 924 bp, rpb2 779 bp, rpb1 $1005 \mathrm{bp})$, respectively. The ITS and the concatenated 5-locus datasets used in the analyses consisted of 37 (Table 1) and 33 (Table 2) sequences, respectively, and both using $R$. glutinosa Fatto and $R$. glutinosoides Buyck \& X. H. Wang as outgroups. A rapid bootstrapping (BS) algorithm of 1000 replicates was executed in RAxML 7.2.6 (Stamatakis 2006), followed by a heuristic ML search for the best tree using the GTRGAMMA model. All parameters in RAxML analysis were kept at default. Bootstrap value (BS) exceeding 70\% was considered to be significantly supported. 
TABLE 2. - Sequences used in phylogenetic analysis based on 5-locus data (LSU-mtSSU-tef1-rpb2-rpb1). Specimens in bold correspond to new species.

\begin{tabular}{|c|c|c|c|c|c|c|c|}
\hline \multirow[b]{2}{*}{ Taxon } & \multirow[b]{2}{*}{ Voucher specimen } & \multirow[b]{2}{*}{ Location } & \multicolumn{5}{|c|}{ Accession number } \\
\hline & & & nucLSU & mtSSU & rpb1 & rpb2 & tef1 \\
\hline R. acrifolia Romagn. & 543/BB 08.662 & Italy & KU237535 & KU237381 & KU237684 & KU237821 & KU237965 \\
\hline & & Canada & & U237320 & U237625 & KU237762 & KU237907 \\
\hline R. aff. areolata Buyck & 79/BB 06.090 & Madagascar & U237471 & KU237315 & - & KU237757 & KU237903 \\
\hline$R$. aff. earlei Peck & 1181/MT s.n. & Costa Rica & KU237598 & KU237446 & - & KU237883 & - \\
\hline R. albonigra (Krombh.) Fr. & 544/BB 07.291 & Slovakia & U237536 & KU237382 & KU237685 & KU237822 & KU237966 \\
\hline R. albonigra (Krombh.) Fr. & AT2002064 (UPS) & Sweden & Q422029 & - & - & DQ421966 & - \\
\hline R. archaeosuberis Sarnari & 1118/BB 12.085 & Italy & KU237593 & KU237441 & KU237732 & KU237878 & KU238019 \\
\hline R. camarophylla Rom & 081108 (PC) & France & Q421982 & - & - & DQ421938 & - \\
\hline marophylla Romagn. & 639/MPG11-7-09 & Spain & U237579 & KU237427 & KU237722 & KU237865 & KU238006 \\
\hline R. cf. eccentrica Peck & 431/BB 07.132 & United States & KP033489 & KU237341 & KU237 & KP033500 & KU237926 \\
\hline R. cf. $s$ & & & & & 237690 & & KU237972 \\
\hline $\begin{array}{l}\text { R. cortinarioides Buyck, Adam ík, } \\
\text { D.P.Lewis \& V.Hofst. }\end{array}$ & 567/BB 07.103 & United States & KP033491 & KU237402 & - & KP033502 & KU237985 \\
\hline R. densifoli & & & & KU237347 & KU237651 & KU237788 & KU23793 \\
\hline & & States & & - & - & & - \\
\hline R. e & BPL2 & Unite & & - & KT957331 & 391 & - \\
\hline & & & & KU237353 & 57 & & KU237937 \\
\hline & & & & KU2373 & KU237677 & & KU237957 \\
\hline Sarnari & 1178/MF & Italy & KU237597 & KU237445 & - & KU237882 & - \\
\hline R. glutinosa Fatto & $\begin{array}{l}\text { Roody WRWV } \\
04.1154 \text { (holotype) }\end{array}$ & United States & MN315511 & MN315532 & - & MN326798 & MN326799 \\
\hline $\begin{array}{l}\text { R. glutinosoides Buyck \& } \\
\text { X.H.Wang }\end{array}$ & $\begin{array}{l}\text { HKAS106678 } \\
\text { (holotype) }\end{array}$ & China & MN428827 & MN460313 & - & - & - \\
\hline Buyck & $2 / \mathrm{B}$ & & & & - & KU237736 & KU237886 \\
\hline R. inornata & $571 /$ & Madagascar & 558 & KU237406 & - & KU23 & KU237989 \\
\hline $\begin{array}{l}\text { R. khanchanjungae Van de Putte, } \\
\text { K.Das \& Buyck }\end{array}$ & $\begin{array}{l}\text { AV-KD-KVP09-106 } \\
\text { (GENT) }\end{array}$ & India & JN389004 & - & JN389201 & JN375607 & - \\
\hline R. lateriticola (R.Heim) Singer & 7/BB 06.031 & Madagascar & KP033487 & KU237297 & KU237604 & KP033498 & KU237888 \\
\hline $\begin{array}{l}\text { R. latolamellata Y.Song \& } \\
\text { L.H.Qiu, sp. nov. }\end{array}$ & $\begin{array}{l}\text { GDGM } 79561 \\
\text { (holotype) }\end{array}$ & China & MK881933 & MK882061 & MT085500 & MK880660 & MT085574 \\
\hline $\begin{array}{l}\text { R. latolamellata Y.Song \& } \\
\text { L.H.Qiu, sp. nov. }\end{array}$ & GDGM 79563 & China & MN839557 & MN839605 & MT085525 & МT085632 & MT085604 \\
\hline R. nigricans Fr. & 429/BB 07.342 & Slovakia & KU237495 & KU237339 & KU237643 & KU237781 & KU237924 \\
\hline R. nigricans Fr. & $\begin{array}{l}\text { UE20.09.2004-07 } \\
\text { (UPS) }\end{array}$ & Sweden & DQ422010 & - & - & DQ421952 & - \\
\hline $\begin{array}{l}\text { R. nigrocarpa S.Y.Zhou, Y.Song } 8 \\
\text { L.H.Qiu, sp. nov. }\end{array}$ & $\begin{array}{l}\text { \& GDGM } 79720 \\
\text { (holotype) }\end{array}$ & China & MN839585 & MN839635 & MT085531 & МT085662 & МТ085630 \\
\hline $\begin{array}{l}\text { R. ochrobrunnea S.Y.Zhou, } \\
\text { Y.Song \& L.H.Qiu, sp. nov. }\end{array}$ & $\begin{array}{l}\text { GDGM } 79718 \\
\text { (holotype) }\end{array}$ & China & MN839584 & MN839634 & - & MT085661 & MT085629 \\
\hline R. polyphyllinae & $737 / \mathrm{BB} 09.215$ & New Caledonia & & & - & KU237875 & - \\
\hline & & & & KU237403 & KU237700 & KP033503 & KU237986 \\
\hline $\begin{array}{l}\text { R. pseudoaurantiophylla Buyck \& } \\
\text { V.Hofst. }\end{array}$ & 740/BB 09.219 & New Caledonia & KU237591 & KU237439 & KU237730 & KU237876 & KU238017 \\
\hline
\end{tabular}

\section{RESULTS}

\section{PHYLOGENETIC ANALYSES}

The final alignments of the ITS and 5-locus datasets used in Maximum Likelihood analyses were $759 \mathrm{bp}$ and $4179 \mathrm{bp}$, and the resulting trees are shown in Figures 1 and 2, respectively.

Subgenera Archaeae and Compactae were fully resolved in both phylogenetic analyses $(\mathrm{BS}=100 \%)$ with all three newly proposed species nested in subg. Compactae. Russula ochrobrunnea S.Y.Zhou, Y.Song \& L.H.Qiu, sp. nov., was highly supported as member of a clade corresponding to sect. Polyphyllae Buyck \& V.Hofst. (BS $=100 \%)$ in both analyses and placed sister with full support $(\mathrm{BS}=100 \%)$ to $R$. eccentrica Peck. The other two novel species were placed with significant support $(\mathrm{BS}=82 \%)$ by our multilocus analysis (Fig. 2) in a clade that corresponds to sect. Nigricantinae Bataille, but could not be placed with significant support to any particular species in the ITS analysis (Fig. 1) whereas, in our multilocus analysis, $R$. latolamellata Y.Song \&
L.H.Qiu, sp. nov., maintains an isolated position and $R$. nigrocarpa S.Y.Zhou, Y.Song \& L.H.Qiu, sp. nov., is grouped with $R$. acrifolia Romagn. with full support (BS = 100\%).

TAXONOMY

Phylum BASIDIOMYCOTA R.T.Moore

Class AGARICOMYCETES Doweld

Order RUSSULALES Kreisel ex P.M.Kirk, P.F.Cannon \& J.C.David

Family RussulaceAe Lotsy Genus Russula Pers.

Subgenus Compactae (Fr.) Bon

Russula latolamellata Y.Song \& L.H.Qiu, sp. nov. (Figs 3; 4)

MYCOBANK NUMBER. — MB 835726. 
Holotype. - China. Guangdong Province, Zhaoqing City, Dinghushan Biosphere Reserve, on the ground in broadleaf forest, 6.IV.2015, J. B. Zhang K15060604 (GDGM 79561).

ETYMOLOGY. - Named after its broad lamellae.

DiAGNOSIS. - Mainly characterized by its distinctly cracking and black-tan pileus, broad and sparse lamellae, stipe and context becoming scarlet when bruised, basidiospores with completely reticulate ornamentations, common presence of 1-spored basidia, encrusted hyphae with brown pigments in pileipellis and absence of both pileocystidia and caulocystidia.

HABITAT AND DISTRIBUTION. - Solitary or gregarious in broadleaf forest.

Additional specimens examined. - China. Guangdong Province, Zhaoqing City, Dinghushan Biosphere Reserve, on the ground in broadleaf forest, 13. IX. 2016, J. W. Li, Y. Song K16091311 (GDGM 79562); 13.VII.2015, J. W. Li, Y. Song K17071307 (GDGM 79563).

\section{DESCRIPTION}

Basidiomata

Medium to large sized, agaricoid.

\section{Pileus}

6-12 cm in diameter, hemispherical when young, becoming applanate with a slightly depressed center when mature; surface dry, cracking, tan, grayish to blackish brown, not easy to peel; margin entire or undulate.

\section{Lamellae}

Adnate, sparse, up to $8 \mathrm{~mm}$ broad, irregularly unequal, sometimes forked near stipe or at pileus margin, sometimes interveined; surface smooth, white, off-white to cream, tinged with reddish brown; lamella edge concolorous.

\section{Stipe}

4-8 cm long, central, cylindrical, sometimes tapering upwards or downwards, longitudinally rugulose, white to off-white, becoming grayish white when old, turning reddish-brown to scarlet when bruised, solid or stuffed.

\section{Context}

White, becoming reddish-brown when bruised, turning yellowish-brown in reaction with $5 \% \mathrm{FeSO}_{4}$.

\section{Odour}

Slightly unpleasant.

\section{Taste}

Mild.

Spore print

White.

\section{Basidiospores}

Subglobose to ellipsoid, [100/5/3] (5.9-) 6-6.8-7.4 (-7.5) $\times$ (4.9-) 5.1-5.8-6.5 (-6.9) $\mu \mathrm{m}, \mathrm{Q}=(1.04-)$ 1.06-1.17-1.32 $(-1.37)$; ornamentations amyloid, composed of low ridges, forming a complete reticulum; suprahilar spot inamyloid.

\section{Basidia}

41-60 × 6-12 $\mu \mathrm{m}$, clavate to narrowly clavate, 1-, 2-, 3- or 4 -spored, hyaline or containing oil droplets; sterigmata 4.8$8.3 \times 1.4-2.2 \mu \mathrm{m}$

\section{Lamellar trama}

Composed of nested sphaerocytes measuring 18.5-55.5 $\times$ $17-43 \mu \mathrm{m}$ and surrounded by connective hyphae.

\section{Pleurocystidia}

(35.5-) 38-62-83 (-91) × (4.5-) 6-7.5-10 $\mu \mathrm{m}$, protruding up to $30 \mu \mathrm{m}$, narrowly clavate to narrowly cylindrical with obtuse or mucronate apices, thin-walled, with refractive contents, unchanging in SV.

\section{Cheilocystidia}

(34-)39-43-47(-51) × 4.5-5-6.5 $\mu \mathrm{m}$, resembling pleurocystidia in shape but smaller in size, thin-walled, with refractive contents, unchanging in SV.

\section{Marginal cells}

Not differentiated.

\section{Pileipellis}

Composed of ascending to erect hyphae, orthochromatic in cresyl blue; hyphae 2-6 $\mu \mathrm{m}$ in width, cylindrical, septate, some with incrustation and brown dispersive pigments; terminal cells (8-)11-23-36(-38.5) × 2.5-4-6(-7.5) $\mu \mathrm{m}$, usually cylindrical with obtuse apices and brown pigments, lageniform, clavate to cylindrical, some with short rostrate apicesor granular contents.

\section{Pileocystidia}

None found.

\section{Stipitipellis}

Composed of erect hyphae, 40-90 $\mu \mathrm{m}$ wide; hyphae 1.5-4 $\mu \mathrm{m}$ in width, narrowly cylindrical, septate; terminal cells (6.5-)13$22-31(-39) \times 2-4-6(-7.5) \mu \mathrm{m}$, thin-walled, usually hyaline, cylindrical to clavate with obtuse apices.

\section{Caulocystidia}

None found.

\section{Clamp connections}

Absent.

\section{NOTES}

Russula latolamellata Y.Song \& L.H.Qiu, sp. nov., morphologically resembles $R$. schaefferina Rawla \& Sarwal, including pileus color and features of pileipellis, size and ornamentations of basidiospores and absence of both pileocystidia and caulocystidia, etc. However, it differs substantially from our species in its finely pruinose pileus with uncracking surface, thin and crowded lamellae, and further also by shape and size of pleurocystidia (85-98 $\times$ 10-14 $\mu \mathrm{m})$, and cheilocystidia $(35-50 \times 9-13 \mu \mathrm{m})$, and the 


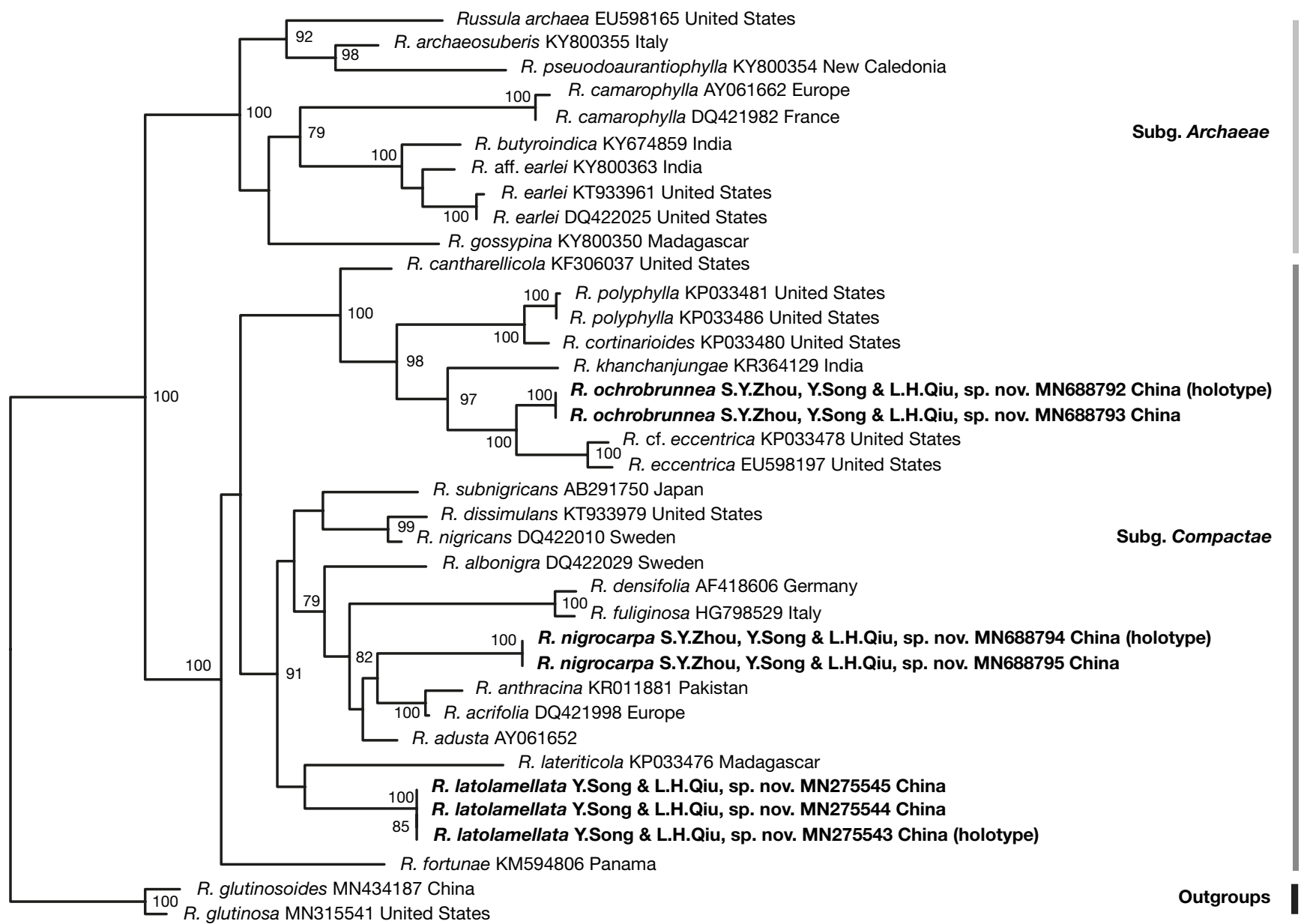

FIG. 1. - Maximum Likelihood tree of Russula Pers. subg. Archaeae Buyck \& V.Hofst. and Compactae (Fr.) Bon based on ITS sequences, bootstrap values higher than $70 \%$ were displayed around nodes. Scale bar: 0.03 substitutions.

hollow stipe covered with ochraceous or brown depressed fibrillose scales (Rawla \& Sarwal 1983). When bruised, context of $R$. latolamellata Y.Song \& L.H.Qiu, sp. nov., directly becomes reddish brown without turning black first.

Although all three specimens of $R$. latolamellata Y.Song \& L.H.Qiu, sp. nov., were collected from the broadleaf forest of DHSBR, several ITS sequences that have a sequence similarity of about $99 \%$ to that of $R$. latolamellata Y.Song \& L.H.Qiu, sp. nov., retrieved from soil in the pine and broadleaf mixed forest of DHSBR are available in GenBank, implying that the species may be common in DHSBR.

Russula nigrocarpa S.Y.Zhou,Y.Song \& L.H.Qiu, sp. nov. (Figs 5; 6)

MYCOBANK NUMBeR. — MB 835727.

Holotype. - China. Guangdong Province, Zhaoqing City, Dinghushan Biosphere Reserve, on the ground in broadleaf forest, 16.VII.2019, S. Y. Zhou K19071603 (GDGM 79720).

Eтyмоlogy. - Named after its dark black pileus.
DiAGNOSIS. - Mainly characterized by its dry, cracking, dark brown to dark black pileus, off-white lamellae, basidiospores with complete reticulate ornamentations, hymenial cystidia and pileocystidia of various forms with often forked apices, strongly glutinous pileipellis composed of hyphae usually with dark brown vacuolar pigments.

HABITAT AND DISTRIBUTION. - Solitary or gregarious in evergreen broadleaf forest.

AdDitionAl SPECIMENS EXAMINED. - China. Guangdong Province, Zhaoqing City, Dinghushan Biosphere Reserve, on the ground in broadleaf forest, 5.V.2018, J. W. Li, Y. Song K18050529 (GDGM 79721).

\section{DESCRIPTION}

Basidiomata

Medium to large sized, agaricoid.

Pileus

6-10 cm in diameter, applanate to concave when mature; surface dry, dark brown to dark black; margin entire, turning slightly upward.

Lamellae

Adnate to slightly decurrent, sparse, 6 pieces of lamellae and lamellulae/cm at the margin of pileus, broad, unequal; surface 


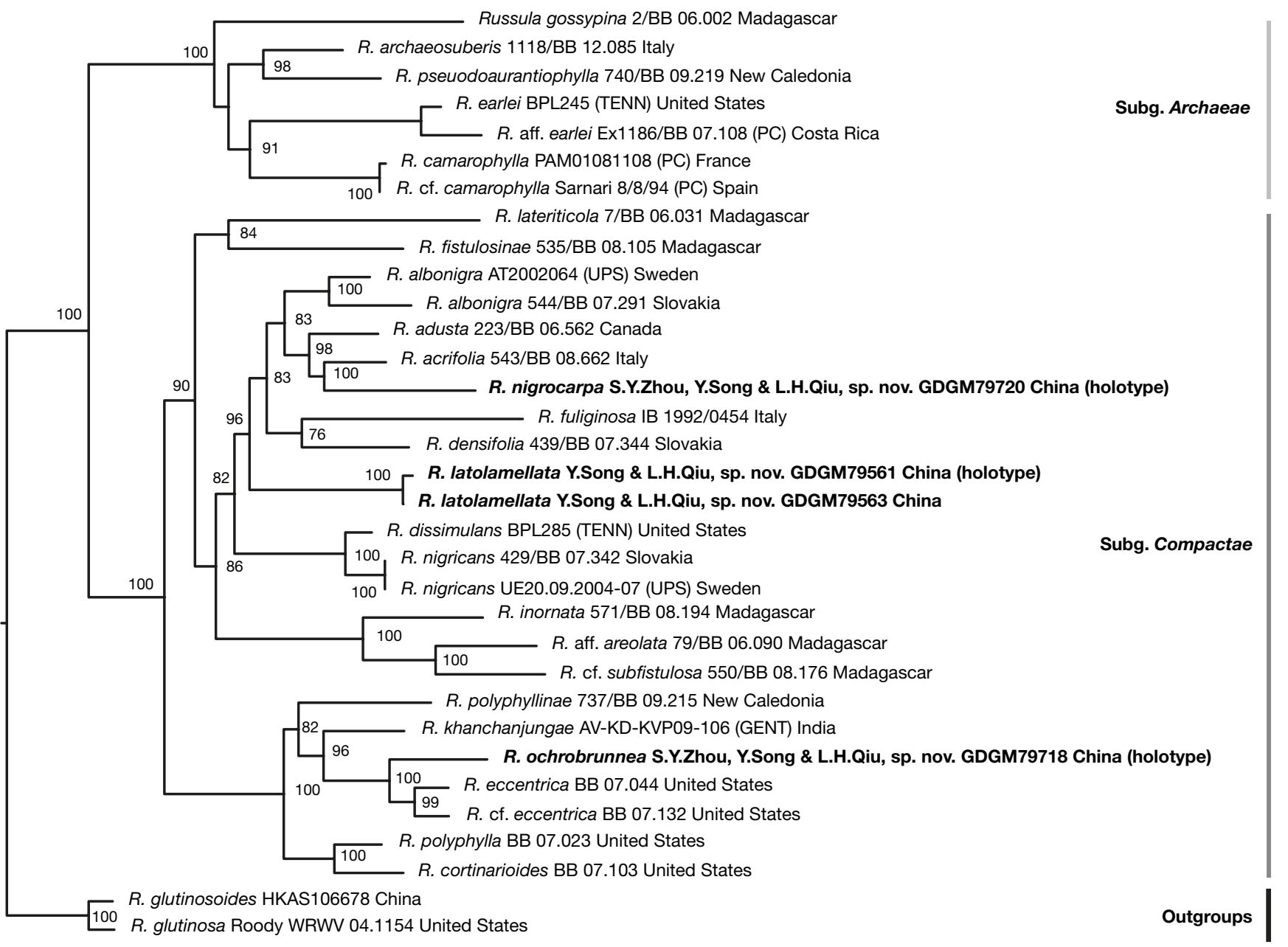

FIG. 2. - Maximum Likelihood tree of Russula Pers. subg. Archaeae Buyck \& V.Hofst. and Compactae (Fr.) Bon based on LSU-mtSSU-tef1-rpb2-rpb1 combined sequences, bootstrap values higher than $70 \%$ were displayed around nodes. Scale bar: 0.02 substitutions.

off-white to cream or yellowish, becoming dark brown when bruised; gill edge concolorous, becoming dark brown to black when old (probably from drying out).

\section{Stipe}

$3-5 \times 2.5-4 \mathrm{~cm}$, central, cylindrical, sometimes tapering downwards, solid, off-white, becoming grayish white when mature, turning dark brown when bruised.

\section{Context}

White, becoming directly black when bruised without reddening first, 6-8 $\mathrm{mm}$ thick near stipe.

\section{Odour}

Unpleasant.

\section{Taste}

Not taken.

Spore print

White to cream.

\section{Basidiospores}

Subglobose to ellipsoid, [40/2/2] 4.3-4.8-5.4 (-5.8) × (3.4-) 3.74-4.4 (-4.6) $\mu \mathrm{m}, \mathrm{Q}=1.10-1.19-1.28$ (-1.35); ornamentations amyloid, composed of low ridges forming a complete reticulum; suprahilar spot inamyloid.

\section{Basidia}

(22-) 26.5-31-35 (-46.5) × 5-6.5-8 $\mu \mathrm{m}$, clavate to cylindrical, 1-, 2-, 3- or 4-spored, with refractive contents; sterigmata 1.8-6 $\mu \mathrm{m}$ long.

\section{Lamellar trama}

Composed of nested sphaerocytes surrounded by connective hyphae.

\section{Pleurocystidia}

(31-) 35-41-52 (-58) × 3.5-5-6.5 $\mu \mathrm{m}$, of various forms, narrowly cylindrical to slightly flexuose with obtuse, mucronate, moniliform, inflorescence-like or forked apices, thin-walled, with refractive contents, unchanging in SV. 

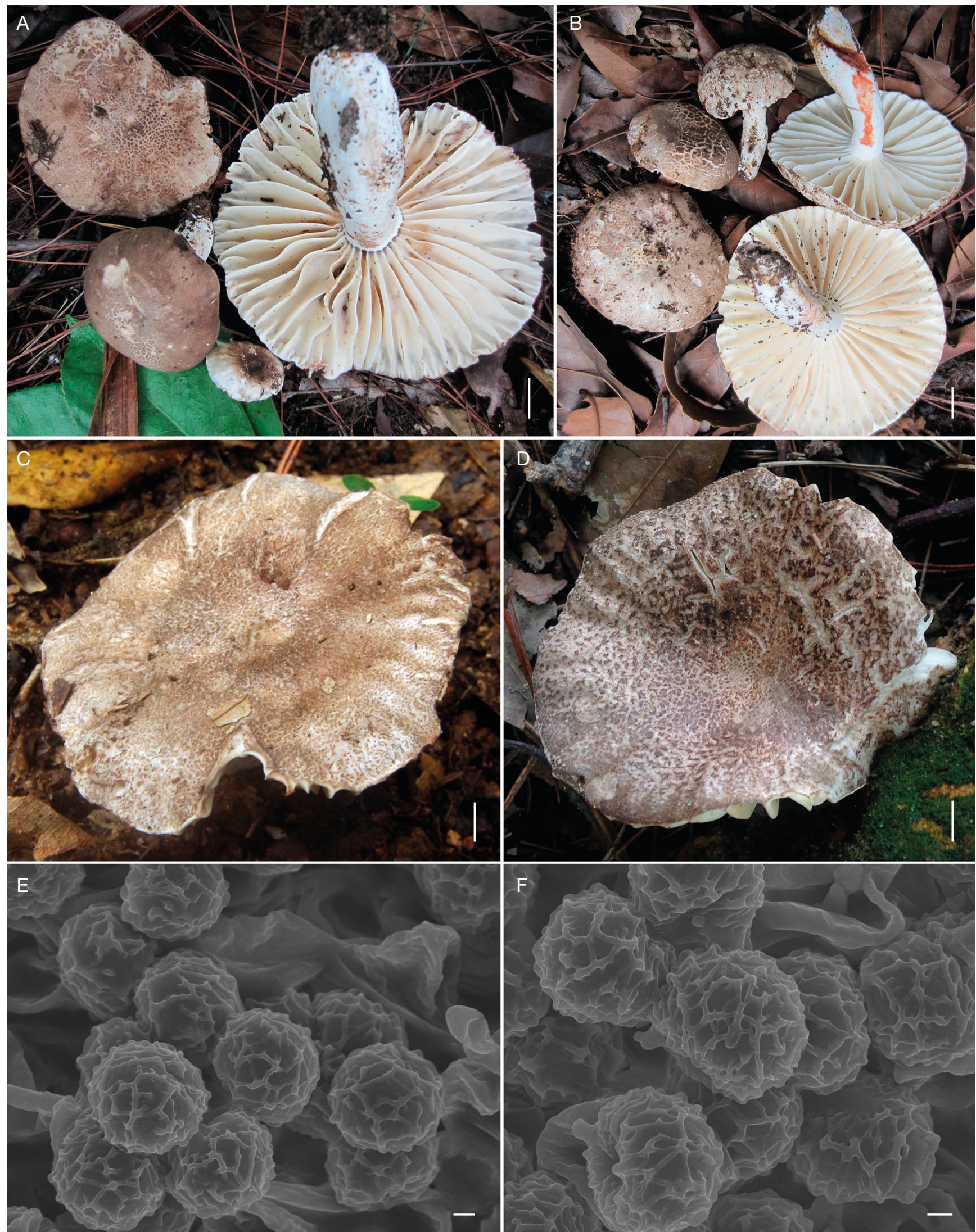

FIG. 3. - Russula latolamellata Y.Song \& L.H.Qiu, sp. nov. (GDGM 79561, holotype): A-D, fruiting bodies; E, F, scanning electronic micrographs of basidiospores. Scale bars: A-D, $1 \mathrm{~cm}$; E, F, $1 \mu \mathrm{m}$. 

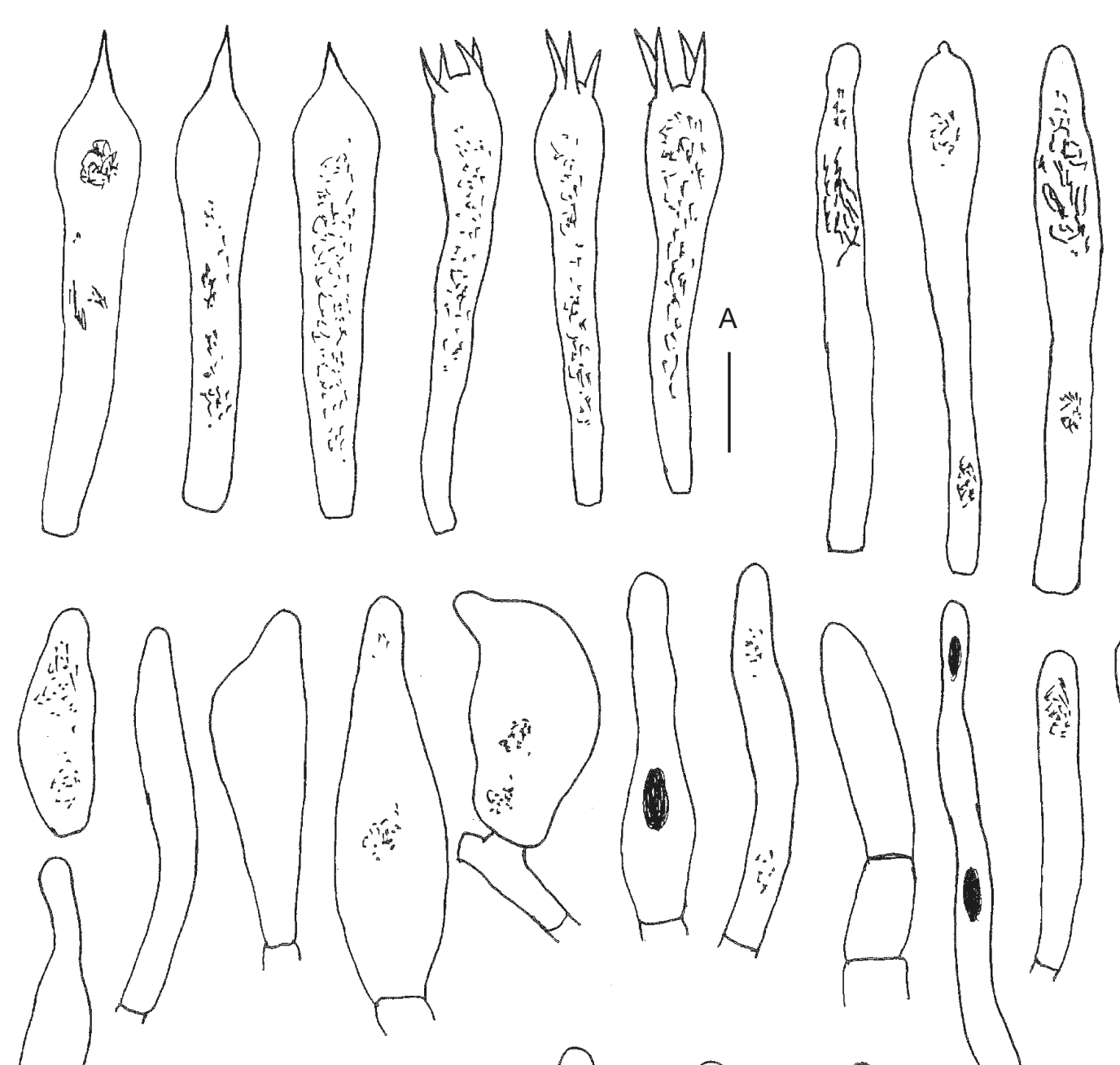

(2)
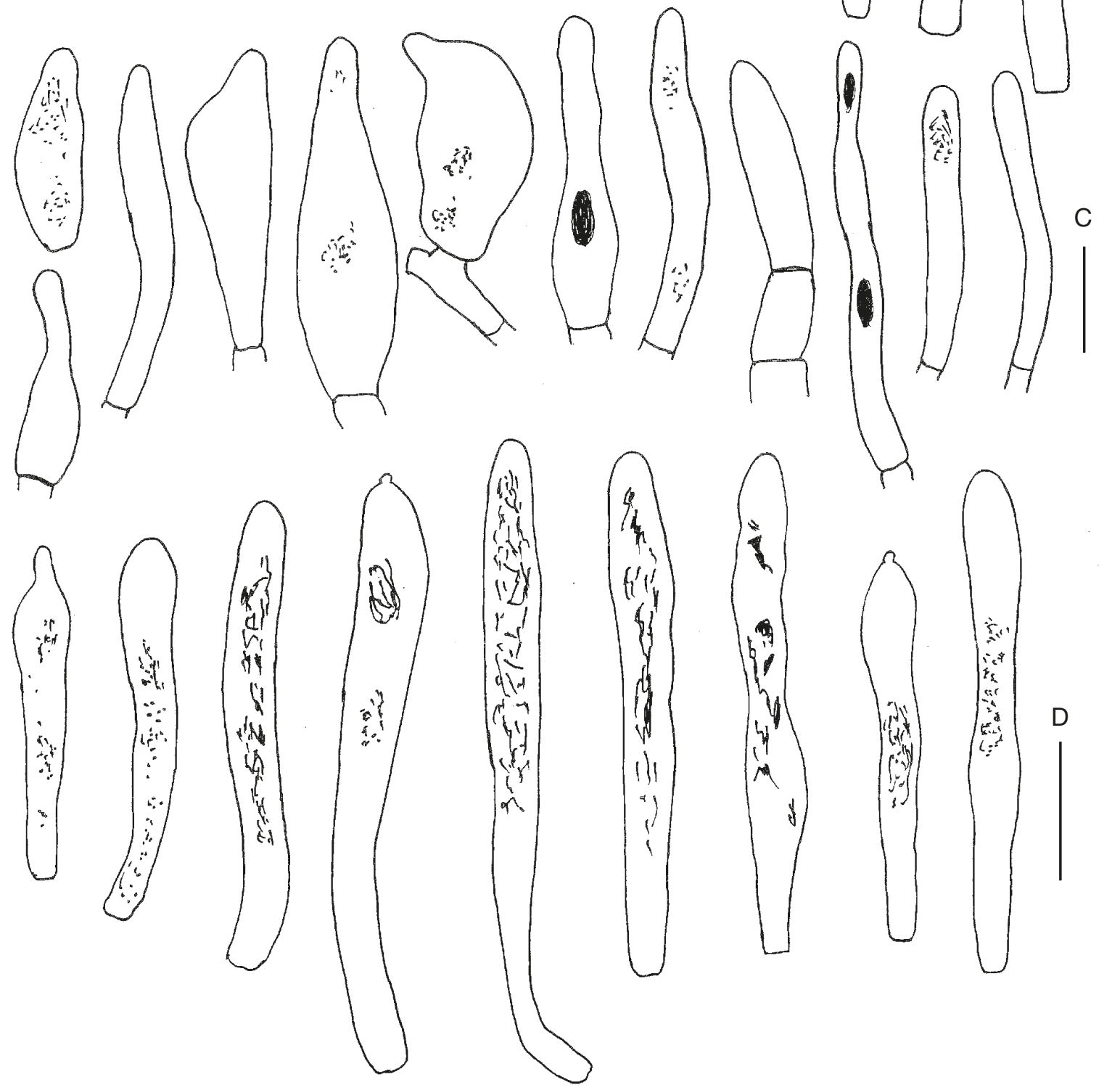


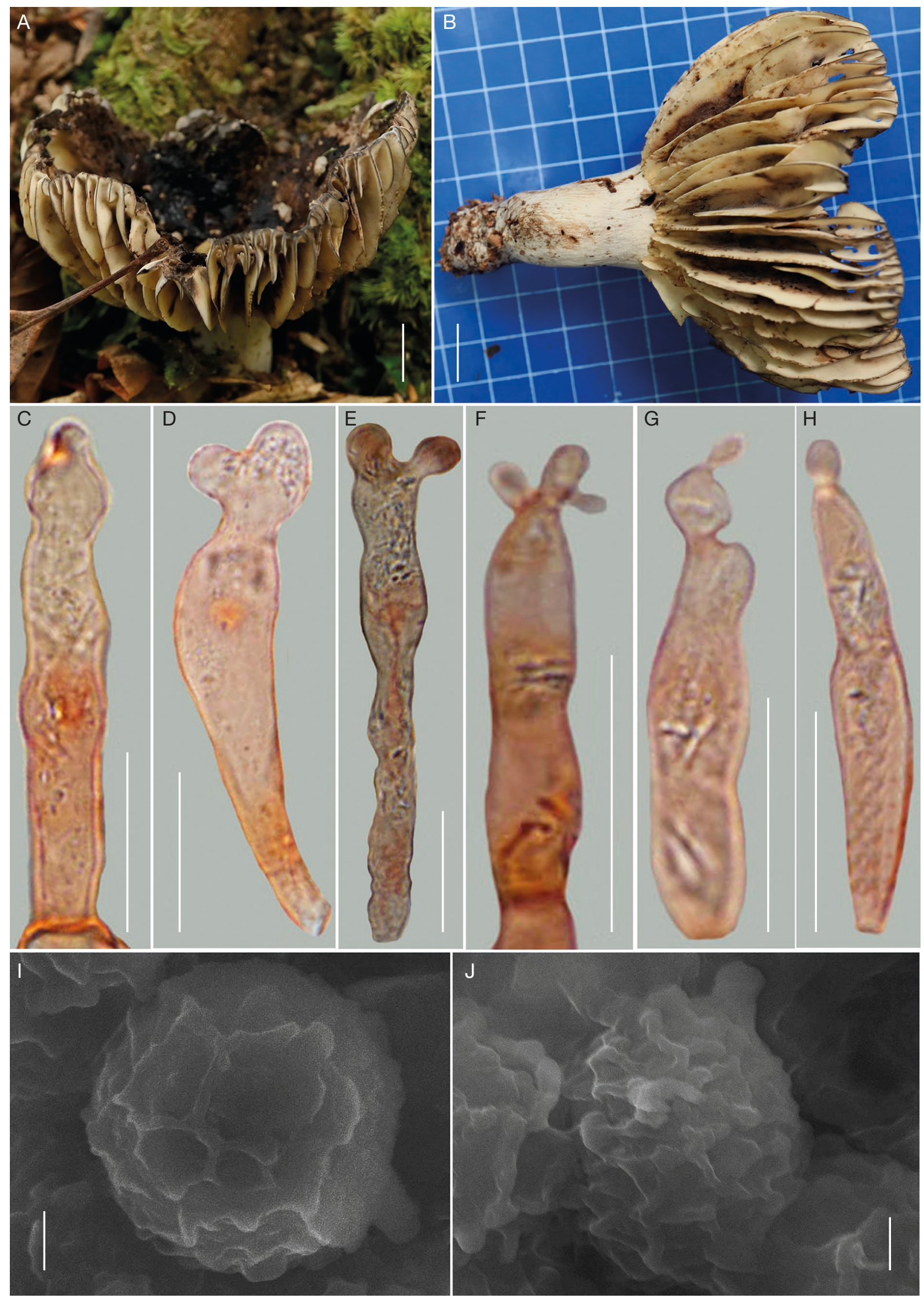

FIG. 5. - Russula nigrocarpa S.Y.Zhou, Y.Song \& L.H.Qiu, sp. nov. (GDGM 79720, holotype): A, B, fruiting bodies; C-E, pleurocystidia; F-H, pileocystidia; I, J, scanning electronic micrographs of basidiospores. Scale bars: A, B, $1 \mathrm{~cm} ; \mathrm{C}-\mathrm{H}, 10 \mu \mathrm{m} ; \mathrm{I}, \mathrm{J}, 1 \mu \mathrm{m}$. 


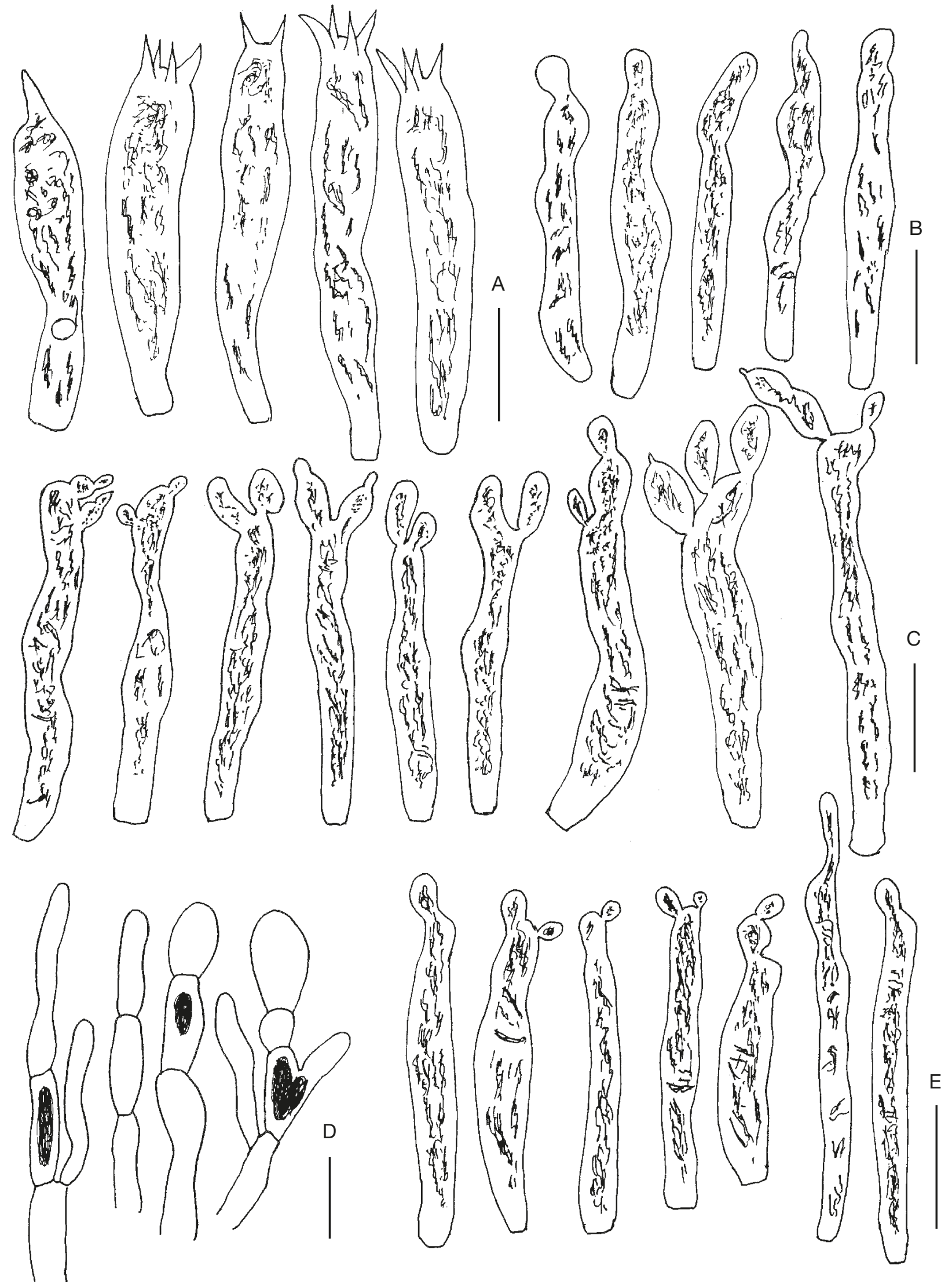



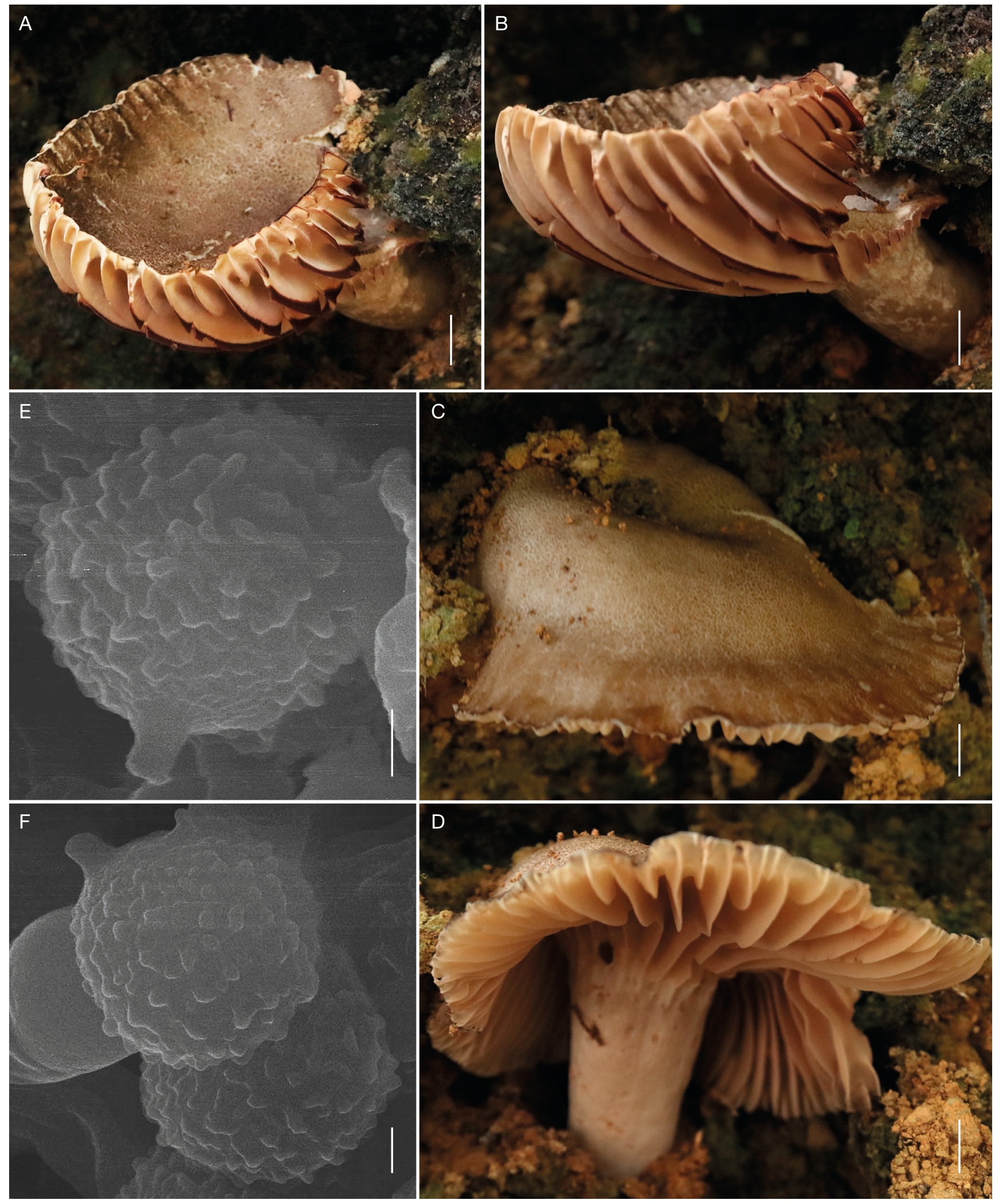

FIG. 7. - Russula ochrobrunnea S.Y.Zhou, Y.Song \& L.H.Qiu, sp. nov. (GDGM 79718, holotype): A-D, fruiting bodies; E, F, scanning electronic micrographs of basidiospores. Scale bars: A-D, $1 \mathrm{~cm}$; E, F, $1 \mu \mathrm{m}$. 

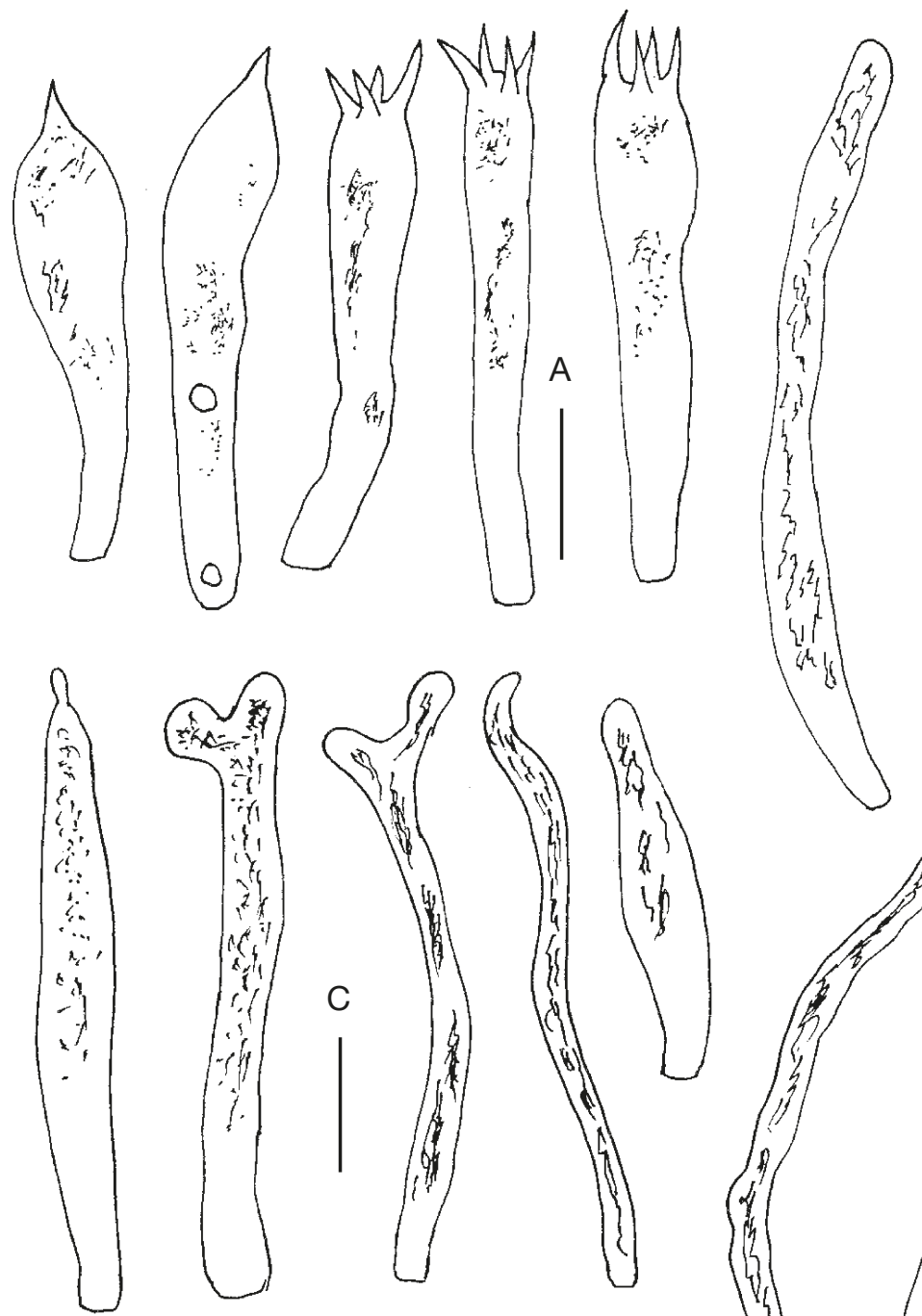

梨闹
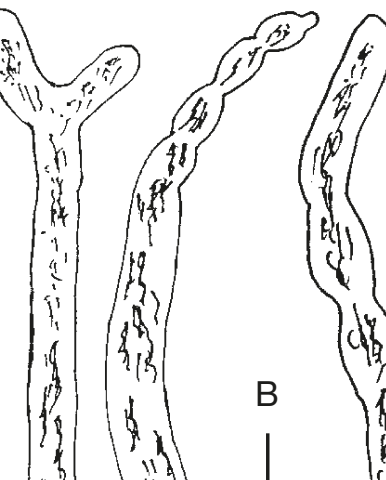

(4)

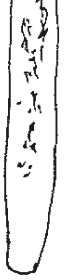

$\left(\begin{array}{l}4 \\ 4 \\ 4 \\ 48 \\ 4 \\ 8\end{array}\right.$
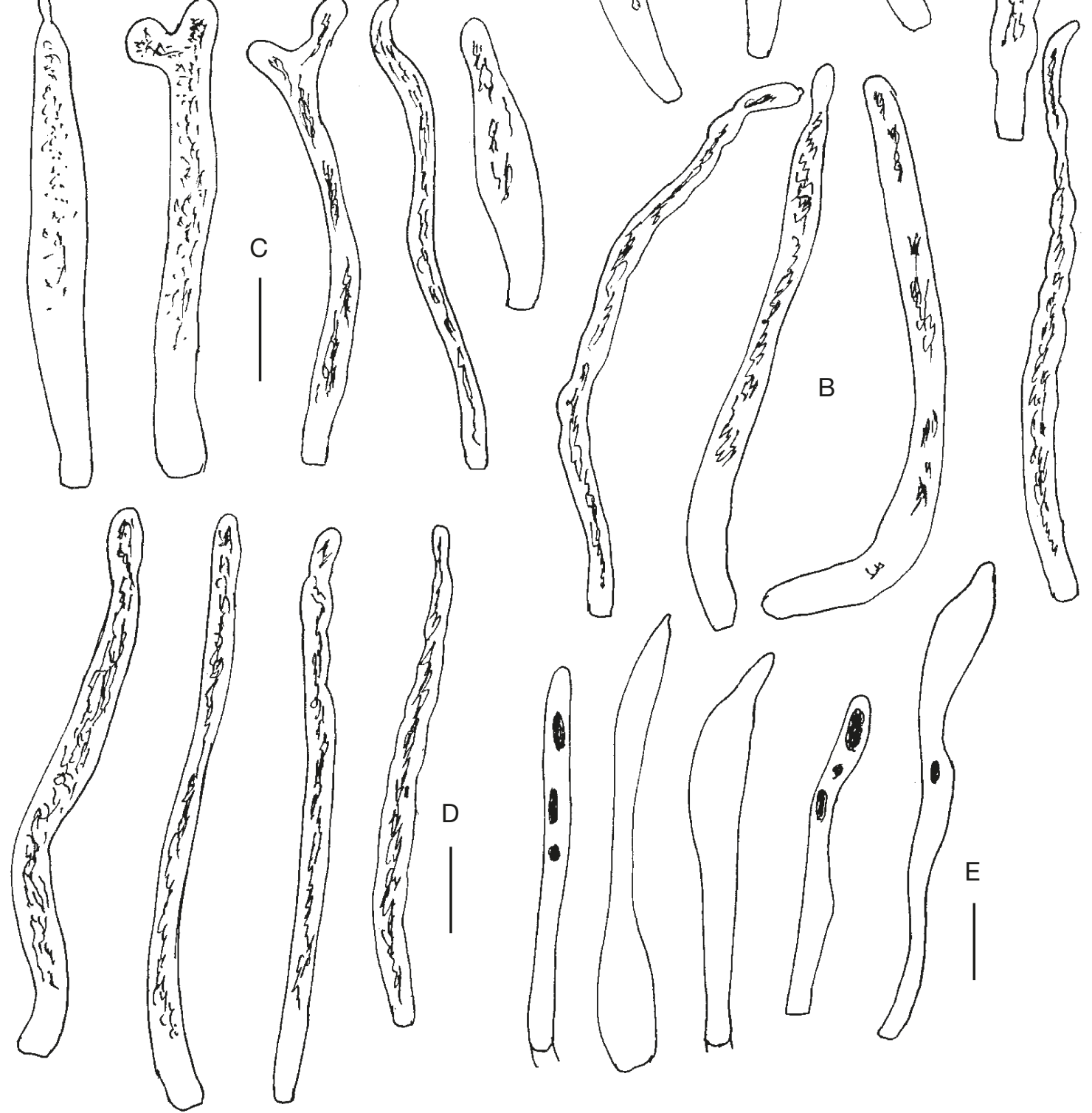

FIG. 8. - Russula ochrobrunnea S.Y.Zhou, Y.Song \& L.H.Qiu, sp. nov. (GDGM 79718, holotype): A, basidia; B, pleurocystidia; C, cheilocystidia; D, caulocystidia; E, terminal elements of pileipellis. Scale bars: A-D, $10 \mu \mathrm{m}$. 


\section{Cheilocystidia}

$25-29-35 \times 3-4-5 \mu \mathrm{m}$, narrowly cylindrical to slightly flexuous with obtuse or rostrate apices, with refractive contents, thin-walled, unchanging in SV.

Marginal cells

Not differentiated.

\section{Pileipellis}

Composed of ascending to erect hyphae, strongly gelatinized, 150-220 $\mu \mathrm{m}$ thick, orthochromatic in cresyl blue; hyphae 2-6 $\mu \mathrm{m}$ wide, narrowly cylindrical, septate, often with dark brown pigments; terminal cells 12.5-17-22 (-25) × 2.5-4-6 $(-7) \mu \mathrm{m}$, cylindrical to narrowly clavate with obtuse or slightly acute apices, some with dark brown pigments.

\section{Pileocystidia}

16.5-25-33.5 × 2.5-4-5.5 $\mu \mathrm{m}$, subclavate to cylindrical, apices mucronate to inflorescence-like, with refractive contents, thin-walled, unchanging in SV.

\section{Stipitipellis}

Composed of ascending to erect hyphae, 60-100 $\mu \mathrm{m}$ thick, gelatinous; hyphae 1.5-4 $\mu \mathrm{m}$ wide, narrowly cylindrical, septate; terminal cells (8-) 10-19-31 (-34) × 2.5-5-9 (-10) $\mu \mathrm{m}$, cylindrical to narrowly clavate with obtuse apices, sometimes containing brown pigments.

\section{Caulocystidia}

(16.5-) 21-34-52 (-56) × 3.5-4.5-6 $\mu \mathrm{m}$, thin-walled, cylindrical with obtuse or short rostrate apices.

\section{Clamp connections}

Absent.

\section{Notes}

$R$. nigrocarpa S.Y.Zhou, Y.Song \& L.H.Qiu, sp. nov., is closely related to $R$. acrifolia in our multilocus phylogeny (Figs $1 ; 2)$. The latter species differs from $R$. nigrocarpa S.Y.Zhou, Y.Song \& L.H.Qiu, sp. nov., in its viscid, grayish brown pileus, context that turns red then gray to black when bruised, much crowded lamellae and grayish brown stipe but, above all, in the much larger size (6.0-9.5 $\times$ 5.5-7.5 $\mu \mathrm{m}$ ) of its basidiospores (Çolak \& Işiloğlu 2016). The exceptionally small size of the spores of $R$. nigrocarpa S.Y.Zhou, Y.Song \& L.H.Qiu, sp. nov., comparable to those of species in subg. Archaeae, was hitherto undocumented within subg. Compactae, making it impossible to confuse our species with any of the other Asian or northern hemisphere species in the same subgenus.

\section{Russula ochrobrunnea S.Y.Zhou, Y.Song \& L.H.Qiu, sp. nov.}

(Figs 7; 8)

MYCOBANK NUMBER. - MB 835743.
Holotype. - China. Guangdong Province, Zhaoqing City, Dinghushan Biosphere Reserve, on the ground in broadleaf forest, 15.VII.2019, S. Y. Zhou K19071502 (GDGM 79718).

ETYMology. - Named after its light brown lamellae with ochre margin when mature.

DiAGNOSIS. - Characterized by its grayish-brown pileus with striate to slightly cracking margin, sparse and light brown lamellae with ochre margin when mature, small basidiospores, presence of 1 -spored basidia, flexuous to cylindrical hymenial cystidia often with papillate or branched apices and hyphae usually with brown pigments in pileipellis.

HABITAT AND DISTRIBUTION. — Solitary or gregarious in evergreen broadleaf forest.

Additional specimens examined. - China. Guangdong Province, Zhaoqing City, Dinghushan Biosphere Reserve, on the ground in broadleaf forest, 2.VI.2018, S. Y. Zhou K18060208 (GDGM 79719).

\section{DESCRIPTION \\ Basidiomata \\ Medium to large sized, agaricoid.}

Pileus

7-9 $\mathrm{cm}$ in diameter, applanate with a depressed center to concave when mature; surface dry, not viscid, grayish-brown to tan, cracking into reticulum; margin slightly undulate or upward, striate.

\section{Lamellae}

Adnate to decurrent, distant (3-4 pieces of lamellae and lamellulae/cm at the margin of pileus), thick, firm, irregularly unequal; light brown to ochre; gill edge concolorous, but becoming tan to dark brown from drying out when old.

Stipe

4-6 $\times 2.4-3 \mathrm{~cm}$, central to eccentric, cylindrical, mostly tapering downwards or slightly curving, solid, off-white.

\section{Context}

White, unchanging, 3-5 mm thick near stipe.

\section{Odour}

Unpleasant.

Taste

Not taken.

Spore print

White.

\section{Basidiospores}

Subglobose to ellipsoid, [40/2/2] (3.9-) 4.1-4.4-4.7 (-5.1) $\times(3.4-)$ 3.5-3.7-4.0 (-4.3) $\mu \mathrm{m}, \mathrm{Q}=(1.09-)$ 1.10-1.18-1.29 $(-1.30)$; ornamentations amyloid, composed of dense warts, some fused into ridges, forming a partial reticulum; suprahilar spot inamyloid. 


\section{Basidia}

(24-) 26.5-32-39 (-42.5) × 4.5-6-7.5 $\mu \mathrm{m}$, clavate to cylindrical, 1-, 2-, 3- or 4-spored, hyaline or containing granular contents.

\section{Lamellar trama}

Composed of nested sphaerocytes surrounded by connective hyphae.

\section{Pleurocystidia}

(60.5-) 71-98-136 (-146.5) × 3.5-4.5-6um, narrowly cylindrical or flexuous with obtuse, mucronate, moniliform or sometimes forked apices, thin-walled, filled with refractive contents, unchanging in SV.

\section{Cheilocystidia}

Resembling pleurocystidia.

\section{Marginal cells}

Not differentiated.

\section{Pileipellis}

A cutis, 70-110 $\mu \mathrm{m}$ thick, strongly gelatinized, orthochromatic in cresyl blue; hyphae 2-6 $\mu \mathrm{m}$ wide, narrowly cylindrical, septate, often with brown pigments; terminal cells (22-) 26-35.5-58 (-63) × 3-5-6 (-7) $\mu \mathrm{m}$, cylindrical to narrowly clavate with obtuse or slightly acute apices, sometimes with brown pigments.

\section{Pileocystidia}

(53.5-) 55-62.5-76 (-90.5) × 3-4.5-7.5 $\mu \mathrm{m}$, cylindrical to fusiform with obtuse, mucronate or forked apices, some filled with refractive contents, negative in SV.

\section{Stipitipellis}

A cutis; hyphae 1.5-4 $\mu \mathrm{m}$ wide, narrowly cylindrical, septate, many with brown pigments; terminal cells cylindrical or lageniform with obtuse apices.

\section{Caulocystidia}

Cylindrical to narrowly clavate with obtuse or slightly acute apices, up to $7 \mu \mathrm{m}$ wide, thin-walled, filled with refractive contents.

\section{Clamp connections}

Absent.

\section{NOTES}

Both our phylogenetic analyses place our species firmly in sect. Polyphyllae Buyck \& V.Hofst., being closely related to the North American $R$. eccentrica and already separated by a much longer branch from the Indian $R$. khanchanjungae Van de Putte, K. Das \& Buyck (Fig. 2). BLAST results of its ITS sequence in GenBank show top scores that are all $<94 \%$ similar to our species, in this case for specimens collected in Japan and Korea (Park et al. 2014). Russula ochrobrunnea S.Y.Zhou, Y.Song \& L.H.Qiu, sp. nov., resembles $R$. eccentrica in overall morphology, but the latter has pink lamellae and much larger basidiospores $(6-7.8 \times 5-6 \mu \mathrm{m})$ and basidia $(52-69 \times 6.5-9.5 \mu \mathrm{m})$ (Adamč́́k et al. 2018). Russula cartaginis Buyck \& Halling, described from Costa Rica (Buyck \& Halling 2004) differs from R. eccentrica and our species in the presence of a brownish gill edge resulting from the presence of colored, branching marginal cells. Typical for most Polyphyllae is the often distinctly inflated lower portion of hymenial cystidia.

The Indian species $R$. khanchanjungae differs particularly by its crowded and forked lamellae becoming brown when bruised, and by the viscid and brown stipe with surface finely cracking exactly as the pileus surface; it also has much larger basidiospores (7.3-9.4 × 6.3-7.8 $\mu \mathrm{m})$ and basidia $(49-61 \times 8-12 \mu \mathrm{m})$, as well as wider pleurocystidia (8-10 $\mu \mathrm{m}$ in width) (Das et al. 2010). Also $R$. purpureonigra differs principally in its larger spores and crowded lamellae (Manimohan \& Latha 2011).

\section{Acknowledgements}

We would like to thank Administrative Bureau of Dinghushan Biosphere Reserve for their assistance in the collection of specimens. This research was partly supported by the Guangdong Province Science and Technology Innovation Strategy Special Fund (Grant No. 2018B020205003) and the Higher Education Teaching Research and Reform Project of Guangdong Province. We thank also Dr K. Das (A.J.C. Bose Indian Botanic Garden, Howrah, India) for access to Indian literature. We appreciate two reviewers (Dr K. Das and another anonymous expert) for comments on this paper.

\section{REFERENCES}

ADAMcIK S. \& Buyck B. 2014. - Type Studies in Russula Subsection Nigricantes from the Eastern United States. Cryptogamie, Mycologie 35 (3): 293-309. https://doi.org/10.7872/crym.v35. iss3.2014.293

ADAMČík S., JANČOVIČOVÁ S. \& BuYCK B. 2018. - The Russulas Described by Charles Horton Peck. Cryptogamie, Mycologie 39 (1): 3-108. https://doi.org/10.7872/crym/v39.iss1.2018.3

BIDARTONDO M. I. \& BRUNS T. D. 2001. - Extreme specificity in epiparasitic Monotropoideae (Ericaceae): widespread phylogenetic and geographical structure. Molecular Ecology 10: 2285-2295. https://doi.org/10.1046/j.1365-294X.2001.01358.x

BuYCK B. 1989. - Révision du genre Russula Persoon en Afrique centrale. Dissertation doctorale, Rijksuniversiteit Gent. Partie générale: 318 p., 98 fig.; partie descriptive: 590 p., 582 fig.; iconographie M.E.B., 444 photos, en deux volumes.

BuyCK B. 1993. - Russula I (Russulaceae), in Rammeloo J. \& HeInEMANN P. (eds), Flore illustrée des champignons d'Afrique centrale. Vol. 15. Ministère de l'agriculture, Jardin botanique national de Belgique, Bruxelles: 335-408.

BuYCK B. \& HALLING R. 2004. - Two new Quercus-associated Russulas from Costa Rica and their relation to some very rare North American species. Cryptogamie, Mycologie 25 (1): 3-13.

Buyck B., Zoller S. \& HofsteTter V. 2018. — Walking the thin line... ten years later: the dilemma of above-versus below-ground features to support phylogenies in the Russulaceae (Basidiomycota). Fungal Diversity 89: 267-292. https://doi.org/10.1007/ s13225-018-0397-5

BuYCK B., WaNG X. H., ADAMČÍKOVÁ K., CABOŇ M., JaNČOVIČOVÁ S., HofsteTter V. \& ADAMČíK S. 2020. — One step closer to 
unravelling the origin of Russula: subgenus Glutinosae subg. nov. Mycosphere 11 (1): 285-304. https://doi.org/10.5943/mycosphere/11/1/6

ÇOLAK Ö. \& IşıILĞLU M. 2016. — The Subgenus Compactae (Russula) species in Turkey. Turkish Journal of Life Sciences 1: 86-95.

DAs K., PutTe K. V. \& BuYcK B. 2010. - New or interesting Russula from Sikkim Himalaya (India). Cryptogamie, Mycologie 31 (4): 373-387.

Das K., Ghosh A., Li J. W., Qiu L. H., Baghela A., Halama M., Hembrom M. E., Mehmood T., Parihar A., Pencakowski B., Bielecka M., ReczyńsKa K., Sasiela D., Singh U., Song Y., ŚWIERKOSZ K., SZCZÉśniaK K., UniYal P., Zhang J. B. \& BuYCK B. 2017. - Fungal Biodiversity Profiles 31-40. Cryptogamie, Mycologie 38 (3): 1-54. https://doi.org/10.7872/crym/ v38.iss3.2017.353

DoYle J. J. \& DoYLe J. L. 1987. — A rapid DNA isolation procedure for small quantities of fresh leaf tissue. Phytochem Bulletin 19: 11-15.

Girlanda M., Selosse M. A., Cafasso D., Brilli F., Delfine S., Fabbian R., Ghignone S., Pinelli P., Segreto R., Loreto F. Cozzolino S. \& Perotto S. 2006. - Inefficient photosynthesis in the Mediterranean orchid Limodorum abortivum is mirrored by specific association to ectomycorrhizal Russulaceae. Molecular Ecology 15: 491-504. https://doi.org/10.1111/j.1365294X.2005.02770.x

Hall T. A. 1999. - BioEdit: a user-friendly biological sequence alignment editor and analysis program for Windows 95/98/NT Nucleic Acids Symposium Series 41: 95-98.

HoNGO T. 1955. - Notes on Japanese larger fungi (6). Journal of Japanese Botany 30 (3): 73-79.

KATOH K. \& STANDLEY D. M. 2013. - MAFFT Multiple Sequence Alignment Software Versions 7: Improvement in Performance and Usability. Molecular Biology and Evolution 30: 772-780. https://doi.org/10.1093/molbev/mst010

LARKIN M. A., BlaCKSHIElDS G., BROWN N. P., CHENNA R., MCGETtigan P. A., McWilliam H., Valentin F., Wallace I. M., Wilm A., Lopez R., Thompson J. D., Gibson T. J. \& HigGINS D. G. 2007. - Clustal W and Clustal X version 2.0. Bioinformatics 23: 2947-2948. https://doi.org/10.1093/bioinformatics/btm 404

Li J. W., Zheng J. F., SONG Y., YuAn F. \& QiU L. H. 2018. Three novel species of Russula from southern China based on morphological and molecular evidence. Phytotaxa 392 (4): 264276. https://doi.org/10.11646/phytotaxa.392.4.2

Looney B. P., Ryberg M., Hampe F., Sánchez-García M. \& MATHENY P. B. 2016. - Into and out of the tropics: global diversification patterns in a hyper-diverse clade of ectomycorrhizal fungi. Molecular Ecology 25: 630-647. https://doi.org/10.1111/ mec. 13506

Looney B. P., Meidl P., Piatek M. J., Miettinen O., Martin F. M., Matheny P. B. \& LabBé J. L. 2018. - Russulaceae: a new genomic dataset to study ecosystem function and evolutionary diversification of ectomycorrhizal fungi with their tree associates. New Phytologist 218: 54-65. https://doi.org/10.1111/nph.15001
Manimohan P. \& Latha K. P. D. 2011. - Observations on two rarely collected species of Russula. Mycotaxon 116: 125-131. https://doi.org/10.5248/116.125

Park M. S., LeE H., OH S., Jung P. E., Seok S. J., Fong J. J. \& Lim Y. W. 2014. - Species delimitation of three species within the Russula subgenus Compacta in Korea: R. eccentrica, R. nigricans, and $R$. subnigricans. Journal of Microbiology 52: 631-638. https://doi.org/10.1007/s12275-014-4168-z

Petch T. 1917. - Additions to Ceylon fungi. Annals of the Royal Botanic Garden, Peradeniya 6 (3): 195-256.

RaWla G. S. \& SARWAL B. M. 1983. - Taxonomic studies on Indian agarics I. Russulaceae. Bibliotheca Mycologica 91: 23-46.

Romagnesi H. 1967. — Les Russules d'Europe et d'Afrique du Nord. Bordas, Paris: 1-998.

SARNARI M. 1998. - Monografia Illustrata del Genre Russula in Europa, prima parte. Associazione Micologica Bresadola, Trento, 799 p.

SHAFFer R. L. 1962. - The Subsection Compactae of Russula. Brittonia 14 (3): 254-284. https://doi.org/10.2307/2805261

Singer R. 1942. - Das system der Agaricales. II. Ann. Mycologia 40: 1-132.

SONG Y., BUYCK B., Li J. W., YUAN F., Zhang Z. W. \& QiU L. H. 2018a. - Two novel and a forgotten Russula species in sect. Ingratae (Russulales) from Dinghushan Biosphere Reserve in southern China. Cryptogamie, Mycologie 39 (3):341-357. https:// doi.org/10.7872/crym/v39.iss3.2018.341

SONG Y., Li J. W., BuYck B., ZHenG J. F. \& QIU L. H. 2018b. Russula verrucospora sp. nov. and $R$. xanthovirens sp. nov., two novel species of Russula (Russulaceae) from southern China. Cryptogamie, Mycologie 39 (1): 129-142. https://doi.org/10.7872/ crym/v39.iss 1.2018.129

STAMATAKIS A. 2006. - RAxML-VI-HPC: maximum likelihood based phylogenetic analyses with thousands of taxa and mixed models. Bioinformatics 22: 2688-2690. https://doi.org/10.1093/ bioinformatics/btl 446

Vellinga E. C. 1988. - Glossary, in Bas C., KuYPer T. H. W., Noordeloos M. E. \& Vellinga E. C. (eds), Flora Agaricina Neerlandica. A. A. Balkema, Rotterdam: 54-64.

VISSER S. 1995. - Ectomycorrhizal fungal succession in jack pine stands following wildfire. New Phytologist 129: 389-401. https:// doi.org/10.1111/j.1469-8137.1995.tb04309.x

White T. J., Bruns T., LeE S. \& TAYlor J. 1990. - Amplification and direct sequencing of fungal ribosomal RNA genes for phylogenetics. PCR protocols: a Guide to Methods and Applications 18: 315-322.

YUAN F., SONG Y., BUYCK B., LI J. \& QIU L. H. 2019. - Russula viridicinnamomea F. Yuan \& Y. Song, sp. nov. and $R$. pseudocatillus F. Yuan \& Y. Song, sp. nov., two new species from southern China. Cryptogamie, Mycologie 40 (1): 45-56. https://doi.org/10.5252/ cryptogamie-mycologie2019v40a4

Zhang J. B., LI J. W., Li F. \& QIU L. H. 2017. — Russula dinghuensis sp. nov. and $R$. subpallidirosea sp. nov., two new species from southern China supported by morphological and molecular evidence. Cryptogamie, Mycologie 38 (2): 191-203. https://doi. org/10.7872/crym/v38.iss1.2017.191 